\title{
Sistematização de imagens arquetípicas para 0 design
}

Ravi Passos é Doutor em Design pela Universidade Aveiro; mestre em Design pela Universidade Anhembi Morumbi; especialista em Arte, Educação e Tecnologias Contemporâneas pela Universidade de Brasília; Bacharel em Desenho Industrial, com habilitação em Programação Visual, pela Universidade de Brasília. Docente em cursos relacionados ao design, na Universidade Federal de Goiás. Atua na pesquisas e desenvolvimentos em design, com ênfase em design da informação, voltados à interface digital, interação, programação visual, identidade e metodologia de projeto, entre outros. Tem interesses no enfoque da criação experimental, na conscientização de processos e na facilitação social direcionada à diversidade e ao suporte a grupos em vulnerabilidade.

<ravipassaos@ufg.com>

ORCID: 0000-0002-9420-982X
Resumo A configuração da informação é elemento fundamental no ofício de design, entretanto, o reconhecimento e uso consciente de imagens neste processo, em relações às suas tipologias, ainda é tema pouco apontado na literatura. 0 presente artigo apresenta uma discussão acerca de conceitos sobre arquétipo, imagem arquetípica e estereótipo, no contexto do design da informação, a fim de auxiliar na identificação e análise de imagens arquetípicas que são utilizadas no design de artefatos gráficos, tais como capas de livros, cartazes cinematográficos e capas de álbuns musicais. A partir de uma abordagem analítica e exploratória, com auxílio de instrumento bibliográfico, propõe-se como resultado um quadro analítico a respeito de conceitos utilizados para categorização de imagens que pode favorecer o processo de design.

Palavras chave Design da informação, Imagens-arquetípicas, Arquétipos, Estereótipos. 
Jéssica Mastrela é Bacharel em Design Gráfico pela Faculdade de Artes Visuais da Universidade Federal de Goiás. Atua em pesquisas e desenvolvimentos na área do design tais como ilustração científica, projeto editorial e identidade. Tem interesse na interdisciplinaridade do design em relação a psicologia e antropologia nos processos de criação e organização imagética, sua fundamentação teórica e seus impactos sociais. $<j . m a s t r e l a 98 @ g m a i l . c o m>$ ORCID: 0000-0001-6591-1284

\section{Systematization of archetypal images for design}

Abstract The configuration of information is a fundamental element in the design work, however, the recognition and conscious use of images in this process, in relation to their typologies, is still a topic that has not been mentioned in the literature. This article presents a discussion regarding the concepts of archetype, archetypal image and stereotype, in the information design context, in order to assist in the identification and analysis of archetypal images that are used in graphic design artifacts, such as book covers, movie posters and music album covers. Based on an analytical and exploratory approach, with the aid of a bibliographic instrument, as a result an analytical framework of concepts used for categorizing images that can contribute to the design process is proposed.

Keywords Information design, Archetypal images, Archetypes, Stereotypes.

\section{Sistematización de imágenes arquetípicas para el diseño}

Resumen La configuración de la información es un elemento fundamental en el oficio del diseño, sin embargo, el reconocimiento y uso consciente de las imágenes en este proceso, en relación a sus tipologías, sigue siendo un tema poco mencionado en la literatura. Este artículo presenta una discusión sobre conceptos relacionados con el arquetipo, imagen arquetípica y estereotipo, en el contexto del diseño de la información, con el fin de ayudar en la identificación y análisis de imágenes arquetípicas que se utilizan en el diseño de artefactos gráficos, como portadas de libros, carteles de películas y portadas de álbumes de música. Con base en un enfoque analítico y exploratorio, con la ayuda de un instrumento bibliográfico, se propone un marco analítico para el resultado de conceptos utilizados para categorizar imágenes que pueden favorecer el proceso de diseño.

Palabras clave Diseño de la información, Imágenes arquetípicas, Arquetipos; Estereotipos. 


\section{Introdução}

Arquétipos permeiam a sociedade de diversos modos, relacionando-se às variadas experiências do curso da vida humana, seja manifestando-se por meio de sonhos, mitos, histórias, contos, imagens espontâneas ou elaboradas, ou ainda, relacionando-se ao comportamento de indivíduos ou agrupamentos sociais. Contudo, geralmente, os arquétipos dificilmente são percebidos em si, pelo sujeito comum, que lidará com os mesmos de maneira espontânea (JUNG, 2002; HILLMAN, 1995). Do mesmo modo, estereótipos também são parte constituinte das experiências humanas e se fazem expressamente presente no espectro social, pessoal e midiático, em contrapartida ao caso dos arquétipos, podendo ser identificados com facilidade pelo sujeito comum (BARROS, 2009; LIPPMAN, 1922).

Embora ambos os termos (arquétipos e estereótipo) sejam aplicados em diferentes circunstâncias e diferentes áreas do conhecimento, ambos detêm conceitos que apresentam uma íntima relação com manifestações imagéticas (BARROS, 2009; GUERRA, 201-?; HILLMAN, 1995; JUNG, 2002; SERBENA, 2010) e entende-se que, por esse motivo, não é incomum deparar-se com eles na experiência acadêmica e na prática do design, em diferentes disciplinas, no que tange a consecução de imagens. Desse modo, entende-se ser importante a realização da presente discussão sob a ótica do esclarecimento acerca desses conceitos em vista da compreensão do uso de imagens arquetípicas no contexto do design, auxiliando assim o designer na projeção de interações mais eficientes de interfaces digitais e analógicas, pelo viés de tornar compreensível e consciente os processos envolvidos no projeto relativos à configuração da informação (design da informação).

\section{Método empregue}

Diante do exposto, o presente trabalho propõe uma discussão a partir de uma abordagem exploratória, utilizando como instrumento o levantamento bibliográfico e a análise paramétrica, sendo regida por fundamentos do design da informação, de conceitos e teorias sobre imagem arquetípica e estereótipo e, por consequência, de conceitos e teorias sobre arquétipo e inconsciente coletivo, em vista de se parametrizar conceitos em uma proposição de sistematização voltada ao design.

É importante ressaltar que este trabalho é tratado a partir de uma perspectiva heurística do uso dos conceitos e teorias utilizados, configurando, portanto, uma análise particular do assunto em questão, afim de se fundamentar uma análise prática para a categorização de imagens. 


\section{Objetivos}

Esse trabalho tem como objetivo geral a proposição de um quadro analítico de categorização de imagens arquetípicas, por meio do levantamento bibliográfico e da análise paramétrica, em vista de uma sistematização, para auxílio no desenvolvimento de artefatos gráficos relacionados ao design da informação, favorecendo, assim, as ações conscientes intrínsecas aos processos de configuração da informação.

Para a realização de tal objetivo geral, colocam-se como objetivos específicos do trabalho, delimitar propriedades relativas a imagens arquetípicas inerente aos sujeitos no âmbito do design da informação; auxiliar no uso de imagens arquetípicas relacionados à configuração de artefatos gráficos; colaborar na fundamentação dos estudos teórico sobre o design da informação no que tange o fenômeno de interação entre o sujeito e a informação e; analisar as relações que se configuram entre imagens arquetípicas e seus assuntos relacionados.

\section{Referencial teórico}

Para estruturar a discussão proposta, apresentam-se de modo conciso, conceitos e teorias fundamentais para a corporificação da presenta investigação, de acordo com a relevância e inter-relação entre os temas elencados.

\section{0 design da informação}

O design da informação é uma subárea do design que se encarrega de tornar informações o mais claras possível e simplificá-las para que sejam acessíveis de modo a facilitar a compreensão e utilização das mesmas pelo usuário de forma eficiente e efetiva (HORN, 1999; KATZ, 2012; PASSOS, 2014). Esse processo, de configurar a informação, se dá por meio do uso de métodos que possibilitem a otimização "de estrutura, significado e uso pelo sujeito em contexto determinado." (PASSOS, 2014, p. 68).

0 design da informação utiliza diferentes recursos para apurar a comunicação entre o objeto e o usuário. Segundo Horn (1999), um dos objetivos primários da área é projetar interações que sejam fáceis, naturais e o mais agradáveis possível. Para tal faz-se uso de certas ferramentas tais como: ilustrações, gráficos, infográficos, ícones, layouts, textos e símbolos, dentre outras (PETTERSSON, 2012). Desse modo, entende-se que a compreensão a respeito da relação entre as imagens e o modo como o sujeito a compreende, pelo viés de seus processos mentais, é fundamental para o cumprimento a que se destina o design da informação. 


\section{0 inconsciente coletivo e os arquétipos}

Reconhecida com uma das primeiras discussões sobre o inconsciente coletivo na teoria de ideias elementares, Adolf Bastian (1826-1905) afirma existir uma unidade psíquica geral da humanidade a qual rege certas ideias elementares comuns a todos (ENCYCLOPÆDIA BRITANNICA, 201-?), porém o teórico não elabora de modo completo o que é essa unidade ou o que são essas ideias (BALDUS, 1966). Em contrapartida o psiquiatra Carl Gustav Jung (1875-1961) retoma e conceitua essa ideia em sua teoria do inconsciente coletivo, como discorrido a seguir.

A discussão acerca do inconsciente transita por diferentes vertentes, tal como a freudiana, que o apresenta como uma "página em branco", Diferentemente, Jung (2002) difere sua conceituação na medida em que amplia a dimensão do inconsciente, que passa a carregar estruturas e imagens comuns a toda humanidade, deste modo, a própria consciência estaria inserida no inconsciente. Segundo esta linha teórica, o inconsciente coletivo é um substrato psíquico comum de natureza suprapessoal que existe em todos os indivíduos, possuindo conteúdos e modos de comportamentos idênticos em todos os seres humanos. (JUNG, 2002)

A palavra arquétipo tem origem no grego arkhétypon em que arkhé significa princípio, e typon significa modelo, e faz uma de suas primeiras aparições na antiguidade no contexto das ideias platônicas. De acordo com Abbagnano (2007, p.80), arquétipo é "o modelo ou o exemplar original de uma série qualquer". Diferentes pensadores contribuíram para a construção do conceito de arquétipo, seja em uma perspectiva filosófica como Platão e Plotino ${ }^{1}$, teológica como Santo Agostinho ou psicológica como Jung e Hillman.

De modo geral, na perspectiva da psicologia arquetípica, pode se entender arquétipo como um modelo primordial do qual derivam imagens arquetípicas e símbolos. Os arquétipos, se manifestam em todas as culturas, sociedades e momentos históricos. Devido a sua natureza formal-universal eles são suprapessoais, atemporais e desconexos de ligações culturais, relacionando-se diretamente com as situações típicas da vida humana, configurando assim, uma constante antropológica, pois os arquétipos são as estruturas que compõem o inconsciente coletivo e regem a psique humana (HILLMAN, 1995; JUNG, 2002; SERBENA, 2010). Os arquétipos também podem atuar como uma base conceitual "para compreender e explorar todos os tipos de experiências nas quais a função criativa da imaginação esteja presente, isto é, imaginais" (SERBENA, 2010, p.78). 
Imagens arquetípicas

Arquétipos são conteúdos essencialmente inconscientes, que só podem ser acessados por meio de suas manifestações nos planos físico, biológico, social, linguístico e estético, assim, tais manifestações recebem o nome de imagens arquetípicas (HILLMAN, 1995; JUNG, 2002). Imagens arquetípicas diferem dos arquétipos na medida em que se tornam conscientes preenchendo a forma do arquétipo com as experiências pessoais adquiridas por cada indivíduo ao longo de suas vidas (JUNG, 2002).

Um dos fatores que diferenciam um arquétipo de uma imagem arquetípica é sua relação com a universalidade, onde uma imagem arquetípica é automaticamente valorada como "universal, trans-histórica, basicamente profunda, geradora, extremamente intencional, e necessária" (HILLMAN, 1995, p. 36). Para o autor, uma imagem pode considerada arquetípica se ela for considerada a partir de um vasto repertório estético, cultural, simbólico e mitológico; Em contrapartida Durand (2012) afirma que o contexto sociológico influencia diretamente na modelagem dos arquétipos em símbolos, e portanto, mesmo que os arquétipos sejam universais, os símbolos que os representam serão determinados de acordo com o contexto sociológico em que estão inseridos; ainda, para Jung (2002), as imagens arquetípicas, são modeladas de acordo com as experiências vividas pelos indivíduos podendo apresentar-se espontaneamente em sonhos ou de modo elaborado como no caso dos mitos, levando-se à conclusão, portanto, de que as imagens arquetípicas só são relativamente universais de acordo com o contexto ao qual pertencem.

Em suma, imagens arquetípicas são o resultado da aplicação da consciência sobre um arquétipo que, desta forma, ganha uma estrutura metafórica ${ }^{2}$, constituindo parte do repertório imaginário de determinado agrupamento social em acordo com a correspondência de experiências que esse conjunto apresenta. Imagens arquetípicas irão surgir em diferentes locais (históricos e geográficos) apresentando a mesma ideia, porém utilizando-se de motivos e linguagens diferentes justamente por derivarem do mesmo tema arquetipal. Jung (2002) observou essa recorrência em diferentes contos de fadas, mitos e ainda nos comportamentos e sonhos apresentados por seus pacientes. Um exemplo desse fenômeno de recorrência pode ser observado no conto A Polegarzinha (Figura 1) e o conto O Corte do Bambu (adaptado para o cinema sob o nome de O Conto da Princesa Kaguya) (Figura 2) nos quais pode-se encontrar o mesmo tema de uma menina pequenina e delicada que surge de dentro de uma planta diante de uma personagem que não possui filhos. 


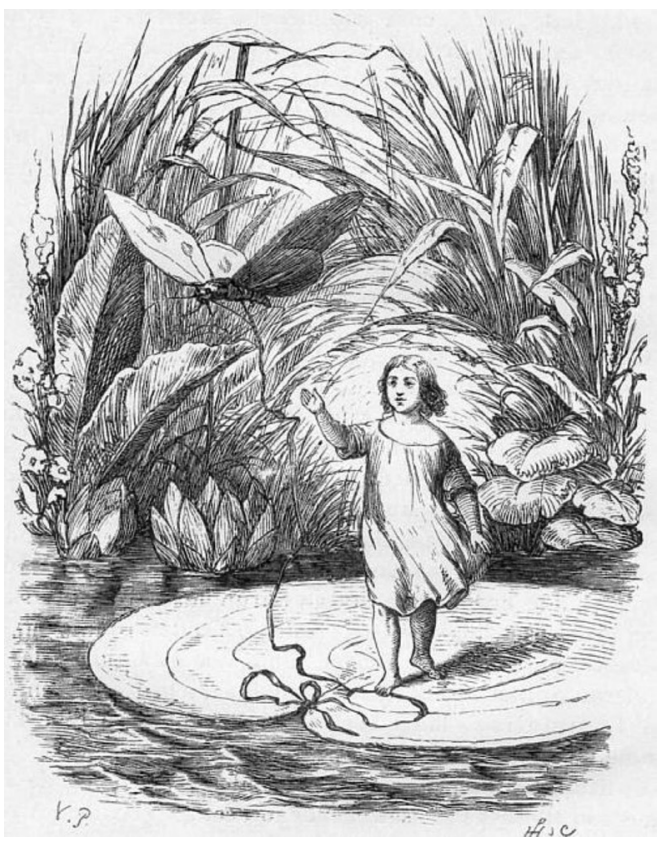

Fig 1. Ilustração de A Polegarzinha por Vilhem Pedersen, em $1835^{3}$.

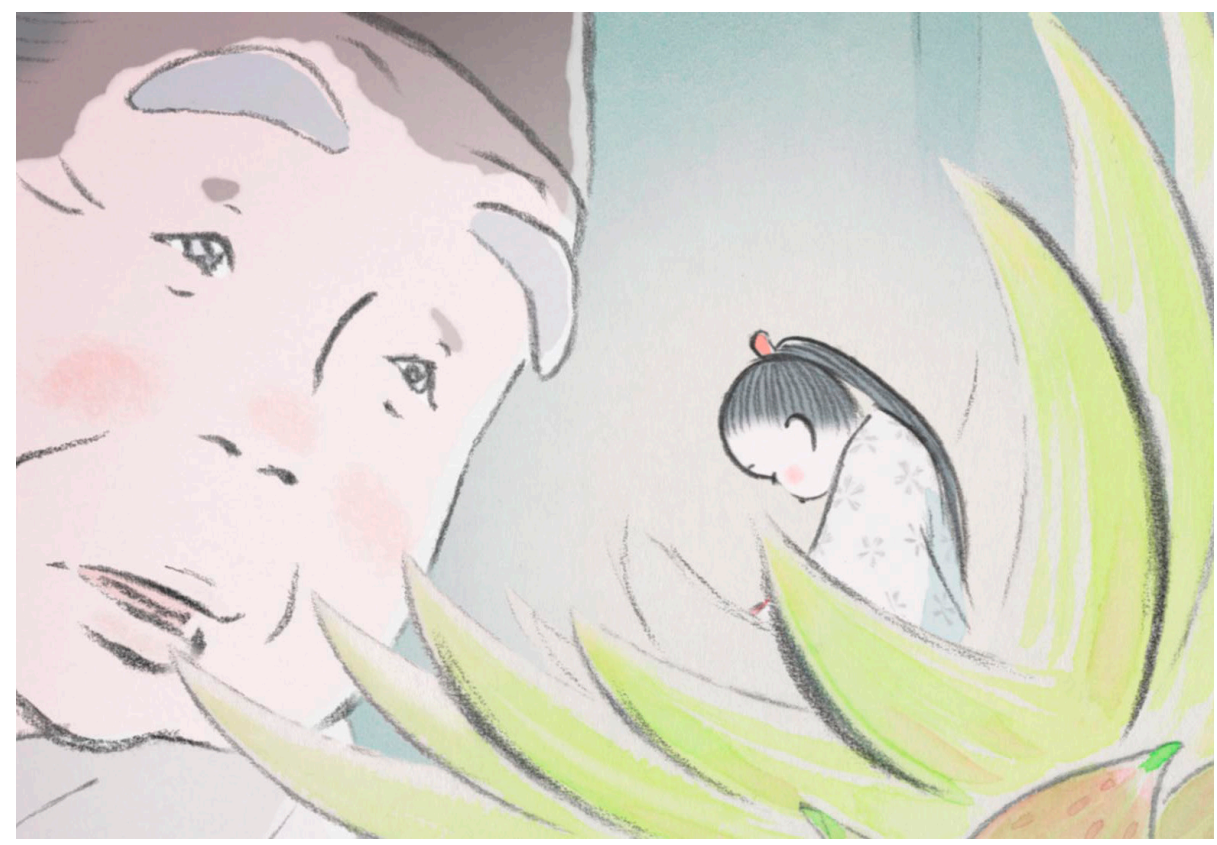

Fig 2. Cena do filme de Isao Takahata, 0

conto da Princesa Kaguya, de 2013.

\section{Estereótipos}

O termo 'estereótipo' também possui origem no grego sendo formado por stereos, que significa rígido, e typos, que significa traço. Inicialmente seu uso era associado somente às impressões gráficas, onde designa uma chapa de metal utilizada para produzir cópias idênticas do mesmo texto (HEITLINGER, 2006). Em um breve levantamento, encontra-se o termo estereótipo definido por Guerra (201-?) como padrões formados por repetição, simplificação e exagero, que surgiram ao decorrer do desenvolvimento das sociedades pela categorização de aspectos relacionados ao comportamento humano e à forma que as pessoas se apresentam socialmente. A partir dessas categorias formaram-se modelos que, ao se repetirem, reforçavam ideias e garantiam uma sensação de validade.

Walter Lippman (1922), considerado fundador da conceituação contemporânea de estereótipo afirma que os estereótipos são parte natural da interação humana com o mundo, sendo uma forma de organização e estruturação da realidade que permeia todo o sistema perceptivo humano. Para o autor os estereótipos são formados pelas preconcepções que o sujeito tem do mundo quando estas encontram um número razoável de confirmações na experiência da realidade, e segundo ele, devido a inevitável necessidade de se economizar atenção, abandonar completamente os estereótipos iria empobrecer a vida humana. 
Krüger (2004, p. 36) por sua vez, define estereótipo como uma

crença coletivamente compartilhada acerca de algum atributo, característica ou traço psicológico, moral ou físico atribuído extensivamente a um agrupamento humano, formado mediante a aplicação de um ou mais critérios, como por exemplo, idade, sexo, inteligência, moralidade, profissão, estado civil, escolaridade, formação política e filiação religiosa.

Segundo o autor, existem estereótipos sociais positivos e negativos e eles podem dividir-se entre o auto estereótipos (que são voltados para um grupo ao qual se pertence); e os hetero-estereótipos (que são voltados a um grupo distinto).

Os estereótipos também podem ter origens arquetípicas quando surgem por meio de um processo de pauperização de uma imagem arquetípica, simplificando os símbolos nela contidos até que estes sejam desvinculados do sentido primário, distanciando-se do arquétipo, restando apenas uma sombra exagerada e simplória da imagem arquetípica original. (BARROS, 2009)

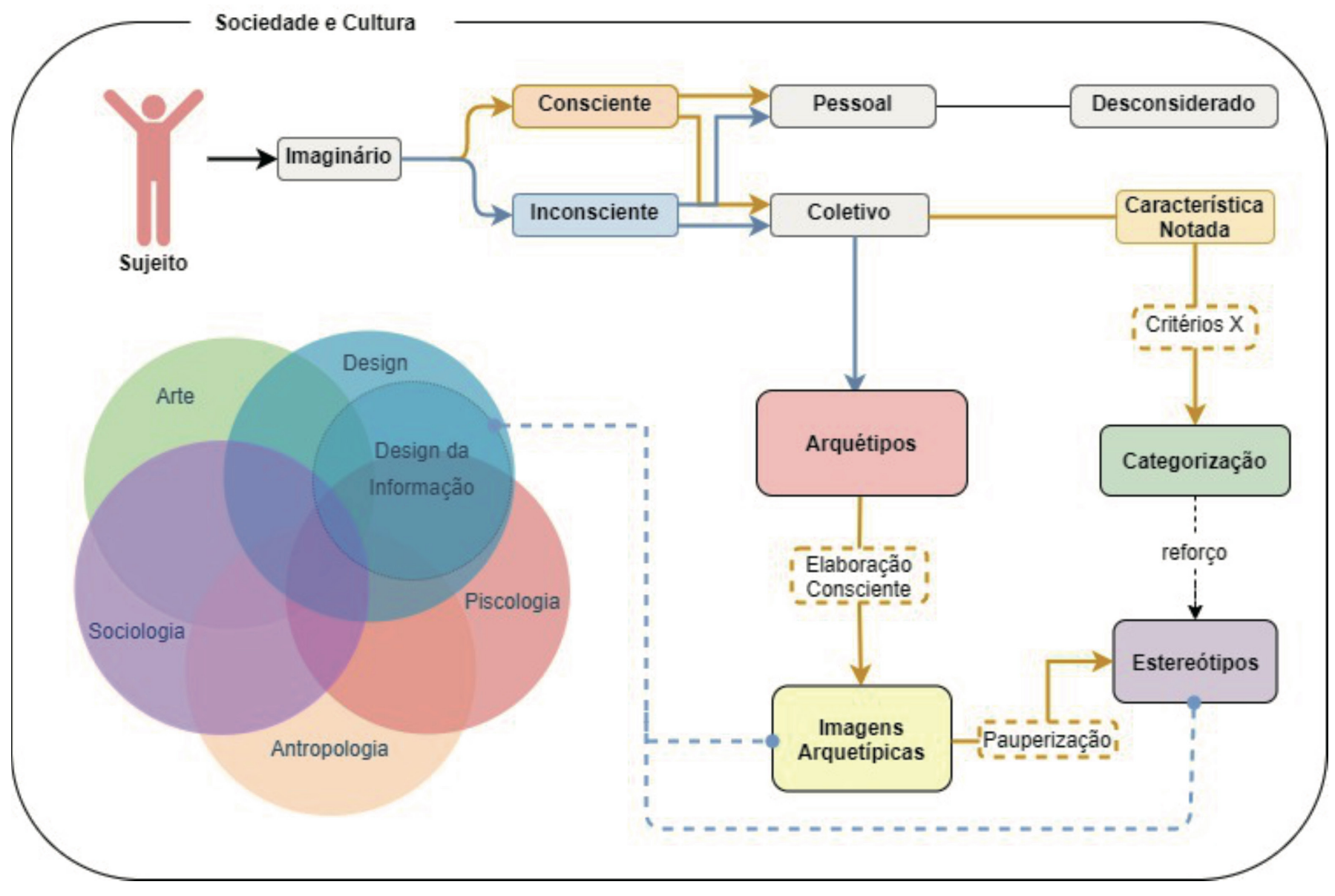

Fig 3. Diagrama analítico sobre fundamentos levantados. 


\section{Relacionando conceitos}

Retomando a discussão na perspectiva do design é necessário compreender as diferenças entre um arquétipo, uma imagem arquetípica e um estereótipo em função de determinar quando se faz oportuno o uso de um tipo entre esses; E poder ainda identificar e categorizar trabalhos já realizados, em que circunstâncias estes são utilizados por seus autores, podendo então compreender, mais adequadamente, quais efeitos cada tipo de imagem suscita no usuário.

Determinar qual a melhor forma de expor um conteúdo é uma das diretrizes do design da informação, tendo em vista que o design, em geral, relaciona-se com ambos tipos de imagens é prudente relacionar o modo que se estabelecem as relações entre os três conceitos especificados nesta investigação. Desta maneira, propõe-se o diagrama (Figura 3) a seguir, desenvolvido a partir da análise dos fundamentos trazidos até o momento.

No diagrama anterior, observa-se que o design da informação, subárea do design, relaciona-se com ambos conceitos de imagens arquetípicas e estereótipos na elaboração de interfaces. As imagens arquetípicas são fruto da elaboração consciente dos arquétipos que povoam o inconsciente coletivo, enquanto os estereótipos surgem de duas maneiras, a primeira, por meio da categorização de características, comportamentos, ideias, (etc.) presentes nos arranjos sociais, a segunda, por meio da pauperização (ou empobrecimento) de uma imagem arquetípica. Ambos conceitos, imagens arquetípicas e estereótipos, são construções conscientes e que neste contexto só são válidas enquanto fenômenos coletivos.

Numa perspectiva mais prática, baseada na pesquisa desenvolvida, a relação entre os conceitos discutidos poderia ser estabelecida da seguinte maneira: $\mathrm{O}$ arquétipo é uma experiência primordial de determinada situação da vida humana, enquanto a imagem arquetípica configura uma representação (imagética, gestual, ou textual) dessa experiência, o estereótipo, por sua vez, é o resultado de uma categorização de tipos de imagens recorrentes, e por fim, o design da informação é um instrumento que atua, entre outras questões, sobre a apresentação gráfica desses conteúdos, por exemplo: tomando-se o arquétipo do Herói em relação às franquias Harry Potter, O Senhor dos Anéis e Star Wars, o arquétipo é a experiência, em todas as óticas possíveis, do que é o herói, cada franquia é uma forma de representar essa experiência, as franquias são imagens arquetípicas, e pode-se tomar um personagem como Harry Potter como um tipo de herói, ou seja um estereótipo de herói, e por fim o design da informação está no tratamento e configuração de informação dos projetos gráficos de cada artefato gráfico utilizado pela franquia, por exemplo nas capas dos livros. 0 design da informação é utilizado na apresentação gráfica desses conteúdos e está presente nas escolhas e na construção da linguagem visual dessas capas, é trabalho do designer determinar quando é mais adequado utilizar uma imagem arquetípica ou um estereótipo nessas interfaces, considerando-se os contextos e necessidades de cada projeto, e visando favorecer a interação entre a interface e o usuário e o conteúdo em questão. 


\section{Desenvolvimento do quadro analítico}

A fim de cumprir o objetivo deste trabalho busca-se desenvolver um instrumento para auxiliar na identificação categorizada de imagens arquetípicas em uso no design. Para tal, elegeu-se os três conceitos identificatórios: Arquétipo, Imagem Arquetípica e Estereótipo. Elegeu-se ainda, uma série de parâmetros de análise que identificam as diferenças entre eles a partir de propriedades gerais. Esses parâmetros foram elegidos de acordo com as conclusões realizadas por meio da discussão aqui realizada, sendo eles: 1 . original; 2. consciente; 3 . de natureza humana; 4 . pessoal; 5 . sócio culturalmente orientado; 6 . síntese; 7 . se apresenta metaforicamente; 8. Complexo; e 9. Universal.

$\mathrm{Na}$ instância deste trabalho, esses parâmetros estarão submetidos a uma interpretação específica, uma vez que os mesmos possuem uma amplitude de significados para diversos contextos. Desse modo fica aqui esclarecido em qual sentido eles foram utilizados: Original, refere-se a um conteúdo bruto, sem formulação prévia, anterior a qualquer representação, ou seja, o conteúdo em si. Consciente, aquilo realizado por meio da razão, que é possível compreender com análises do raciocínio. De natureza humana, tudo aquilo que representa ou remete a situações e experiências típicas da vida humana. Pessoal, aquilo de caráter individual, ou seja, que só faz sentido na escala pessoal devido às experiências únicas que cada indivíduo experimenta no curso de suas vidas (no caso das imagens arquetípicas e dos estereótipos a natureza individual será desconsiderada). Sócio culturalmente orientado, aquilo que só pode ser compreendido sob uma perspectiva contextual, histórica, geográfica e/ou social. Síntese, aqui estabelece-se síntese no sentido atribuído por Kant como "o ato de unir diferentes representações e de compreender essa unidade num único conhecimento" (KANT, Crít. R. Pura, § 10 apud ABBAGNANO, 2007). Metáfora, quando a representação de determinado conteúdo é realizada por meio de uma analogia, estabelecendo assim uma relação de proximidade entre o conteúdo e o objeto usado para representá-lo. Complexo, um conteúdo abundante em símbolos, ideias e conceitos que necessitam um nível intermediário ou alto de conhecimentos prévios interligados para tornar possível a compreensão. Universal, tratado como o conjunto de ideias e conceitos que são reconhecidos e incorporados a toda e qualquer sociedade humana, independente de sua localização geográfica ou histórica.

Cada um dos parâmetros aqui listados (Figura 4) foram selecionados de modo a se estabelecer uma relação dicotômica entre 'sim e não' em relação a cada um dos três conceitos, desta maneira tem-se o parâmetro 1 sendo Original e sua relação com os conceitos de Arquétipo, Imagem Arquetípica e Estereótipo é respectivamente: sim, não e não, conforme tabela 1. 
Tabela 1. Quadro de diferenciação entre os conceitos.

\begin{tabular}{|c|c|c|c|c|}
\hline & PARÂMETROS/CONCEITOS & Arquétipo & $\begin{array}{c}\text { Imagem } \\
\text { Arquetípica }\end{array}$ & Estereótipo \\
\hline 1. & Original & $\operatorname{sim}$ & não & não \\
\hline 2. & Consciente & não & $\operatorname{sim}$ & $\operatorname{sim}$ \\
\hline 3. & De natureza humana & $\operatorname{sim}$ & $\operatorname{sim}$ & $\operatorname{sim}$ \\
\hline 4. & Pessoal & não & não & não \\
\hline 5. & Sócio culturalmente orientado & não & $\operatorname{sim}$ & $\operatorname{sim}$ \\
\hline 6. & É uma síntese & não & $\operatorname{sim}$ & $\operatorname{sim}$ \\
\hline 7. & $\begin{array}{l}\text { É uma representação me- } \\
\text { tafórica de algo }\end{array}$ & $\operatorname{sim}$ & $\operatorname{sim}$ & não \\
\hline 8. & Complexo & $\operatorname{sim}$ & $\operatorname{sim}$ & não \\
\hline 9. & Universal & $\operatorname{sim}$ & não & não \\
\hline
\end{tabular}

Vale ressaltar que o quadro apresentado é o resultado de validações e ajustes sistemáticas realizados a partir de testes empíricos procedidos por meio da análise de imagens aplicadas em contexto de projetos de design de artefatos gráficos. A seguir será apresentado o processo de uso do mesmo.

\section{Análise de imagens a partir do quadro proposto}

Como mencionado, foram realizadas análises imagéticas utilizando o quadro proposto com a finalidade de aplicação prática, assim com o objetivo de verificar sua eficiência. Para demostrar sua utilização, elegeu-se três tipos de imagens relativas ao universo do design gráfico, sendo elas cartazes cinematográficos, capas de álbuns musicais e capas de livros ilustrados. Para cada tipo foram selecionadas três imagens distintas a serem analisadas sob a mesma hipótese de que estas são imagens arquetípicas.

Para o primeiro tipo de imagem, os pôsteres cinematográficos, levantou-se os filmes O Labirinto do Fauno $(2006)^{4}$, Birdman (2015) e O Cisne Negro (2011), que apresentam em comum uma forte temática psicológica que é apresentada por meio de elementos do fantástico. Para o segundo tipo de imagem, as capas de discos, foram elencadas três capas com temática surrealista produzidas por Storm Thorgerson sendo elas: Wish You were Here (1975), Frances the Mute (2005) e Planet Album (2010). Por fim para 
o terceiro tipo, as capas de livros ilustrados, foram elegidos os seguintes livros de contos de fadas: Little Red Riding Hood (1873), The Ugly Duckling (1894) e O Ganso de Ouro (1905).

A análise proposta por esse trabalho abrange uma ponderação acerca da relação que a imagem estabelece com os parâmetros do quadro em comparação aos resultados apresentados por cada conceito. Deste modo, das análises realizadas, como exemplo de utilização do instrumento desenvolvido, colocam-se três dos artefatos gráficos já mencionados: 'O Labirinto do Fauno' (Figura 4), 'O Ganso de Ouro' (Figura 5) e 'Planet Album' (Figura 6), que apresentam suas relações na tabela 2 , a seguir.

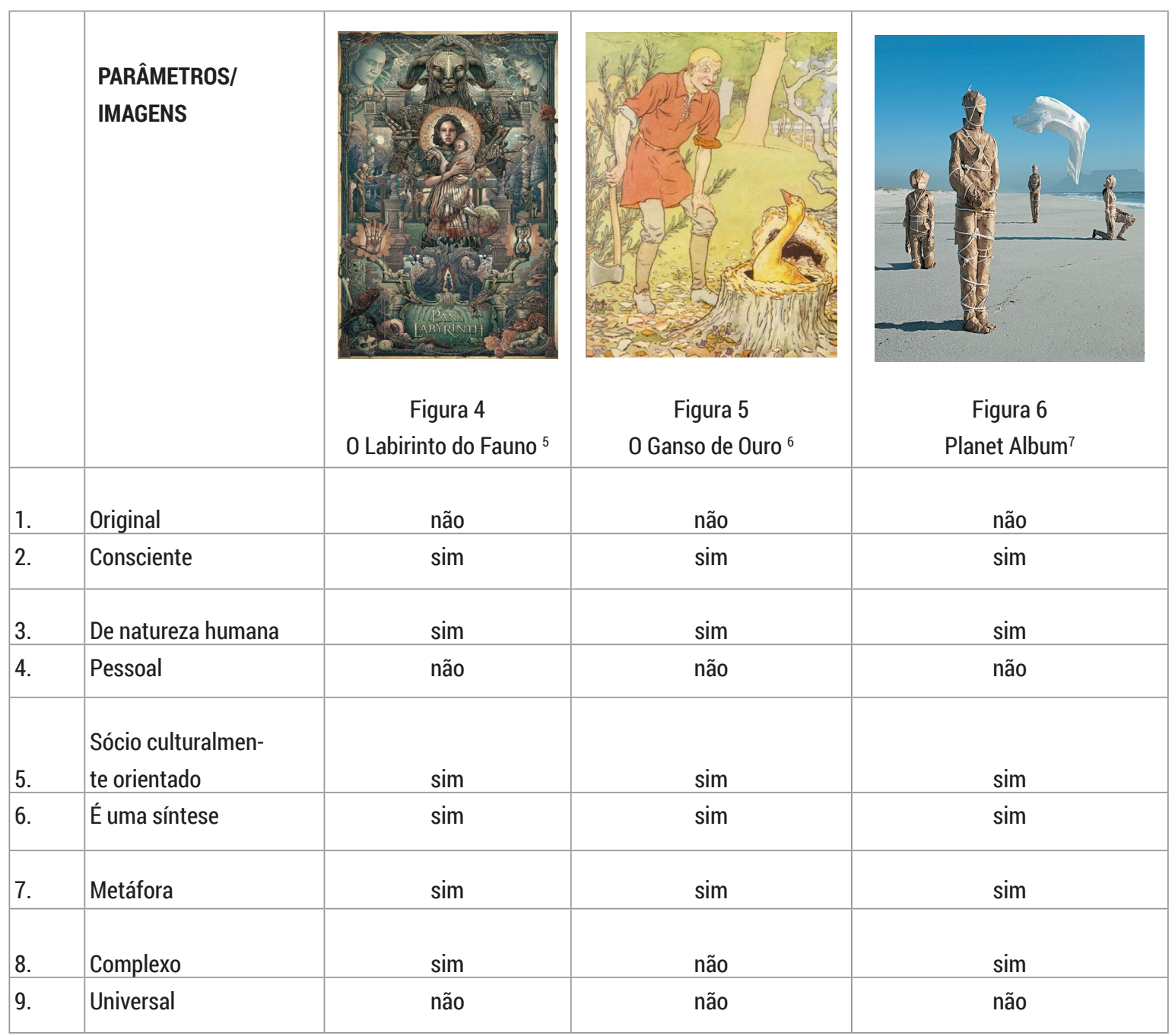

Tabela 2. Análise aplicada do instrumento proposto. 
Comparando o quadro acima de acordo com o quadro de diferenciação (Tabela 1) pode-se concluir que as três imagens apresentadas são imagens arquetípicas, corroborando assim a hipótese proposta. Vale ainda ressaltar que esse resultado foi trazido por um estudo piloto e só é validado pelo contexto deste trabalho, sendo necessária a realização de uma pesquisa de validação mais ampla, envolvendo uma quantidade significativa de usuários para garantir a validade prática de resultados. Entretanto, como o estudo com usuário não faz parte do escopo deste projeto, em sim sua estruturação teórico conceitual, entende-se que o quadro de diferenciação proposto pode auxiliar na identificação de imagens arquetípicas.

\section{Considerações finais}

Muito embora o design pertença à grande área das ciências sociais aplicadas, é possível perceber algumas lacunas conceituais em sua fundamentação disciplinar. Uma delas trata da aplicação de psicologia arquetípica em tarefas relativas à corporificação de artefatos gráficos. A pesquisa realizada, embora apresentada de modo sintético, visou o auxílio contextualizado por meio da aproximação entre a área da psicologia e do design por meio do design da informação. Entende-se que a proposição de um quadro analítico favoreça o processo projetivo de artefatos gráficos de modo consciente em relação ao uso de imagens.

A compreensão dos conceitos e teorias envolvidos com os temas aqui trazidos, nomeadamente, arquétipos, imagens arquetípicas, estereótipos, possibilitou a proposição relacional de um quadro de sistematização auxiliar tanto no projeto como na fundamentação teórica do design no que tange o fenômeno de interação entre sujeito e informação.

Compreender o uso de imagens arquetípicas no design é uma maneira auxiliar no processo de configuração de interfaces que utilizam imagem de modo eficaz e eficiente. Entende-se que a presente investigação pode ter como trabalhos futuros, a realização de validações mais abrangentes, e por essa razão ressalta-se, a importância de se viabilizar outras pesquisas nesse campo.

Percebe-se que, ao longo da execução desse trabalho, o design da informação se mostrou uma ferramenta de aproximação, fazendo uma ponte entre os assuntos ditos de design e outras áreas do conhecimento, abarcando diretamente as experiências humanas tais como a psicologia, sociologia e antropologia. 
1 Há autores como Rafael Rafaelli (2001) que apontam Plotino como o primeiro a abordar o conceito de Arquétipo em um sentido essencialmente psicológico.

2 "Um conteúdo arquetípico sempre se expressa em primeiro lugar metaforicamente." (JUNG, 2002, p.158)

3 Fonte da imagem <https://upload. wikimedia.org/wikipedia/commons/9/9d/Calineczka_VP_ubt.jpeg> Acesso em 10 set 2020.

4 Pôster alternativo produzido por Ise Ananphada.

5 Fonte da imagem: https://hcgart.com/products/princess-of-the-moon-by-ise-ananphada?_pos=2\&_sid=39f652b0d\&_ss=r . Acesso em 10 set 2020.

6 Fonte da imagem: https://pt.wikipedia.org/wiki/O_Ganso_de_Ouro\#/ media/Ficheiro:Simpleton_finds_The_Golden_Goose_-_Project_Gutenberg_eText_15661.jpg . Acesso em 10 set 2020.

7 Fonte da imagem: https://www.stormstudiosdesign. com/\#/203933/2445327/view/ . Acesso em 10 set 2020.

\section{Referências}

ABBAGNANO, N. Dicionário de filosofia. 5a ed. São Paulo: Martins Fontes, 2007.

BALDUS, Herbert. Adolf Bastian. Revista de Antropologia, São Paulo, v. 14, p. 125-130, dec. 1966. BARROS, Ana. A saia de Marilyn: do arquétipo ao estereótipo nas imagens midiáticas. In Revista da Associação Nacional dos Programas de Pós-Graduação em Comunicação | E-compós, Brasília, v.12, n.1, jan./abr. 2009.

DURAND. Gilbert. As estruturas antropológicas do imaginário. $4^{\mathrm{a}}$ ed. São Paulo: Martins Fontes, 2012.

ENCYCLOPÆDIA BRITANNICA. Adolf Bastian. Disponível em <https://www.britannica. com/biography/Adolf-Bastian> Acesso em: 06 set. 2020.

GUERRA, Luiz Antonio. Estereótipo. Disponível em <https://www.infoescola.com/sociologia/estereotipo/> Acesso em: 06 set. 2020.

HILLMAN, James. Psicologia Arquetípica: um breve relato. $9^{\text {a }}$ ed. São Paulo: Cultrix, 1995. HORN Robert E. information design: emergence of a new profession. In JACOBSON, Robert. (Ed.). Information design. Cambridge: MIT Press, 1999.

JUNG, Carl Gustav. Os arquétipos e o inconsciente coletivo. $2^{\mathrm{a}}$ ed. Petrópolis: Editora Vozes, 2002.

KATZ, Joel. Designing Information. 3ª ed. Hoboken, New Jersey: John Wiley \& Sons, Inc. 2012. KRÜGER, Helmuth. Cognição, estereótipos e preconceitos sociais. p. 23-41 In: LIMA, M. \& LIPPMANN, Walter. Public Opinion. New York: Free Press, 1922.

PASSOS, Ravi. Design da informação: um modelo para configuração de interface natural. (Doutorado em Design) - Departamento de Comunicação e Arte, Universidade de Aveiro. Aveiro, Portugal, 2014.

PETTERSSON, Rune. Information Design: an introduction. Amsterdam; Philadelphia: John Benjamins Publishing Company, 2002.

RAFFAELLI, Rafael. Imagem e self em Plotino e Jung. Cadernos de Pesquisa Interdisciplinar em Ciências Humanas, $n^{\circ}$ 22, julho, 2001.

Recebido: 11 de setembro de 2020 . Aprovado: 13 de outubro de 2020.
SERBENA, Carlos A. Considerações sobre o inconsciente: Mito, símbolo e arquétipo na psicologia analítica. Revista da Abordagem Gestáltica - XVI (1): 76-82, jan-jul, 2010. 